\title{
Neonatal cholestasis in congenital pituitary hormone deficiency and isolated hypocortisolism: characterization of liver dysfunction and follow-up
}

\author{
Colestase neonatal na deficiência congênita de hormônio \\ hipofisário e hipocortisolismo isolado: caracterização \\ da disfunção hepática e acompanhamento
}

Débora Braslavsky', Ana Keselman', Marcela Galoppo², Carol

Lezama ${ }^{2}$, Ana Chiesa', Cristina Galoppo², Ignacio Bergadá'

1 División de Endocrinología, Centro de Investigaciones Endocrinológicas (CEDIE); Hospital de Niños Dr. Ricardo Gutiérrez, Buenos Aires, Argentina

2 Unidad 4, Hepatología; Hospital de Niños Ricardo Gutiérrez,

Buenos Aires, Argentina
Correspondence to:

Débora Braslavsky

Gallo 1330

Ciudad Autónoma

de Buenos Aires

CP 1425 - Argentina

dbraslavsky@cedie.org.ar

Received on 9/Oct/2011 Accepted on 17/Oct/2011

\begin{abstract}
Introduction: Neonatal cholestasis due to endocrine diseases is infrequent and poorly recognized. Referral to the pediatric endocrinologist is delayed. Objective: We characterized cholestasis in infants with congenital pituitary hormone deficiencies (CPHD), and its resolution after hormone replacement therapy (HRT). Subjects and methods: Sixteen patients (12 males) were included; eleven with $\mathrm{CPHD}$, and five with isolated central hypocortisolism. Results: Onset of cholestasis occurred at a median age of 18 days of life (range 2-120). Ten and nine patients had elevated transaminases and $\gamma \mathrm{GT}$, respectively. Referral to the endocrinologist occurred at 32 days (range $1-72$ ). Remission of cholestasis occurred at a median age of 65 days, whereas liver enzymes occurred at 90 days. In our cohort isolated, hypocortisolism was a transient disorder. Conclusion: Cholestasis due to hormonal deficiencies completely resolved upon introduction of HRT. Isolated hypocortisolism may be a transient cause of cholestasis that needs to be re-evaluated after remission of cholestasis. Arq Bras Endocrinol Metab. 2011;55(8):622-7
\end{abstract}

Keywords

Cholestasis; congenital hypopituitarism; adrenal insufficiency

\section{RESUMO}

Introdução: A colestase neonatal causada por doenças endócrinas é pouco frequente e reconhecida. Existe um atraso no encaminhamento dos pacientes a um endocrinologista pediátrico. Objetivo: Caracterizamos a colestase em recém-nascidos com deficiências congênitas de hormônio hipofisário (DCHH) e sua resolução após a terapia de reposição hormonal (TRH). Sujeitos e métodos: Dezesseis pacientes (12 do sexo masculino) foram incluídos; sete com $\mathrm{DCHH}$, e cinco com hipocortisolismo central isolado. Resultados: $\mathrm{O}$ início da colestase ocorreu aos 18 dias de vida (variação 2-120). Dez e nove pacientes apresentaram elevação das transaminases e $\gamma \mathrm{GT}$, respectivamente. A consulta com um endocrinologista aconteceu aos 32 dias (variação 1-72). A remissão da colestase ocorreu em uma idade mediana de 65 dias, enquanto a remissão das enzimas hepáticas aconteceu aos 90 dias. Na coorte isolada, o hipocortisolismo foi uma desordem transitória. Conclusão: A colestase causada por deficiências hormonais foi completamente resolvida após a introdução da TRH. O hipocortisolismo pode ser uma causa transitória da colestase e precisa ser reavaliado após a remissão da colestase. Arq Bras Endocrinol Metab. 2011;55(8):622-7

Descritores

Colestase; hipopituitarismo congênito; insuficiência adrenal 


\section{INTRODUCTION}

$\mathrm{T}$ Throughout fetal life, the principal function of the liver is directed towards protein synthesis and hematopoiesis, while maternal liver serves both as a route of elimination of metabolic end-products and as a biotransformation site (1). At birth, the newborn liver begins the process of production and storage of essential nutrients, metabolism of different substances, enzymatic synthesis, and biliary excretion. Modulation of this process depends on structural factors within the liver, nutritional support, and an adequate hormone function. Failure to adapt to these new demands of extra-uterine life associated with the particular vulnerability of the first month of life, results in an alteration of the physiological processes of biliary excretion $(1,2)$.

Cholestasis is defined as an elevation of direct (conjugated) bilirubin (greater than 15\% total bilirubin) (3). Cholestatic jaundice is the typical sign of liver disease. In infants, it becomes quickly apparent, whereas in older children and adults, jaundice usually appears as a later sign. This is in part related to the immaturity of hepatic excretory function of the newborn, also called "physiologic cholestasis" $(2,3)$.

The overall incidence of neonatal liver disease with clinical or biochemical signs of cholestasis is approximately 1:2500 live births. The causes are numerous and highly variable, including obstructive cholestasis (with biliary atresia as the leading cause of neonatal presentation), or intrahepatic cholestasis due to infections, genetic, metabolic, systemic and endocrine disorders. Furthermore, cholestasis can originate from a single cause, or from multiple simultaneous factors.

It has been shown that some hormonal disorders can alter liver function, particularly along the neonatal period. The pattern of liver dysfunction secondary to hormone deficiencies such as growth hormone deficiency, hypocortisolism or hypothyroidism is variable and goes from predominantly indirect hyperbilirubinemia, indirect hyperbilirubinemia that turns into a cholestasis, cholestasis alone, or cholestasis with elevated hepatic enzymes (4).

Congenital pituitary hormone deficiency (CPHD) refers to insufficient trophic pituitary hormones: adrenocorticotropin (ACTH), thyrotropin (TSH), growth hormone $(\mathrm{GH})$, prolactin (PRL) and gonadotropins (LH / FSH), either isolated or combined (5). Since the prevalence of neonatal cholestasis secondary to CPHD is low and generally poorly recognized, referral to the pediatric endocrinologist is frequently delayed. Consequently, many of these patients are exposed to extensive diagnostic tests before coming up to the suspicion of an endocrine disorder.

The purpose of this paper is to describe the clinical, and laboratory evaluation, as well as the follow-up of a cohort of patients with CPHD, with special emphasis on the liver dysfunction and its resolution in relation to hormone replacement therapy (HRT).

\section{SUBJECTS AND METHODS}

We used an observational retrospective design of a series of cases. Patients included had neonatal cholestasis and were referred to the División de Endocrinología from the Hospital de Niños Ricardo Gutiérrez in Buenos Aires, between 2003 and 2010, with abnormal endocrinological assessment due to CPHD.

The following variables were recorded: age at onset of cholestasis, age of endocrine diagnosis, concomitant symptoms and signs suggestive of hormone deficiencies such as hypoglycemia, midline defects (nistagmus, cleft palate, midfacial hypoplasia), open posterior fontanel, abnormal external genitalia in boys (micropenis, microorchidism and/or cryptorchidism), anterior pituitary axes deficiencies, HRT, time to remission of cholestasis and normalization of liver enzymes since HRT was introduced.

The biochemical liver function parameters analyzed were: total and direct bilirubin, aspartate and alanine transaminases (AST, ALT) and gammaglutamiltranspeptidase $(\gamma \mathrm{GT})$, all measured by Vitros DT Dry Chemistry Analyzer (Johnson \& Johnson, U.S.A.).

Hormonal evaluation included determination of TSH, FT4, cortisol, testosterone (EQLIA, Roche Diagnostics GMBH, Mannheim, Germany), GH (CLIA, Immulite 2000, Siemens, Germany), ACTH (EQLIA, Immulite 2000, Siemens, Germany), LH/ FSH (IFMA, Wallac, Perkin Elmer, Finland), and IGF-I (in house RIA).

Hormone deficiencies were diagnosed as follows: central hypothyroidism, when serum FT4 was below $0.8 \mathrm{ng} / \mathrm{dL}$, associated to normal or slightly elevated serum TSH levels for age. Secondary adrenal insufficiency, when serum cortisol was below $1.1 \mu \mathrm{g} / \mathrm{dL}$ at 
less than 2 months of age, and below $2.1 \mu \mathrm{g} / \mathrm{dL}$ in older infants, or below $18 \mu \mathrm{g} / \mathrm{dL}$ under hypoglycemia, with normal or low ACTH. Gonadotropin insufficiency was suspected in boys when serum $\mathrm{LH}$ was $<0.8$ $\mathrm{IU} / \mathrm{L}$, associated to serum levels of testosterone $<10$ $\mathrm{ng} / \mathrm{dL}$, assessed between $\mathrm{l}$ week and 6 months of age; and in girls when serum FSH was $<1.5 \mathrm{IU} / \mathrm{L}$ assessed between 1 week and 12 months of age. GH deficiency was diagnosed when basal serum $\mathrm{GH}$ was $<2 \mathrm{ng} / \mathrm{mL}$ at less than 20 days of life or $<10 \mathrm{ng} / \mathrm{mL}$ under hypoglycemia associated with serum levels of IGF-I below -2 SDS for the age.

After clinical and biochemical diagnosis of CPHD, Magnetic Resonance Imaging (MRI) of the brain, with special exploration of selar area, was performed in all patients.

Patients were classified as harboring multiple or isolated endocrine deficiencies.

\section{RESULTS}

Sixteen patients (12 males) were included: eleven patients with diagnosis of combined CPHD (CCPHD) and five patients with isolated central bypocortisolism. Clinical characteristics and liver function are shown in table 1 .

Onset of cholestasis occurred at a median age of 18 days of life (range 2-120 days). Median conjugated bilirubin was $4.85 \mathrm{mg} / \mathrm{dL}$ (range 1.3 - 20.7 days). Ten patients had elevated levels of transaminases from 2 up to 10 -fold the normal upper limit, and serum levels of $\gamma$ GT were elevated in nine patients. Referral to the endocrinologist occurred at a median of 32 days (range $1-72$ days). Fourteen patients had a history of spontaneous hypoglycemia, recurrent in nine, and severely symptomatic in eight patients, while the rest showed hypoglycemia as a biochemical finding throughout the evaluation of cholestasis (Table 1 ).

Table 1. Clinical characteristics and liver function

\begin{tabular}{|c|c|c|c|c|c|c|c|c|c|c|c|c|}
\hline \multirow{2}{*}{ Pt } & \multirow{2}{*}{$\begin{array}{c}\text { Gender } \\
M / F\end{array}$} & \multirow{2}{*}{$\begin{array}{c}\text { Gestational } \\
\text { age } \\
\text { Weeks }\end{array}$} & \multirow{2}{*}{$\begin{array}{l}\text { Onset of } \\
\text { cholestasis } \\
\text { Age (days) }\end{array}$} & \multirow{2}{*}{$\begin{array}{c}\text { Delayed in } \\
\text { referral to } \\
\text { endocrinology } \\
\text { Time (days) }\end{array}$} & \multicolumn{5}{|c|}{ Liver function } & \multicolumn{2}{|c|}{ Clinical signs } & \multirow{2}{*}{$\begin{array}{l}\text { Follow-up } \\
\text { Time (years) }\end{array}$} \\
\hline & & & & & BiT (mg/dL) & BiD (mg/dL) & AST (IU/I) & ALT (IU/I) & $\gamma \mathbf{G T}(\mathbf{U} / \mathbf{l})$ & Phenotype & Hypoglycemia & \\
\hline 1 & M & 38 & 34 & 1 & 9.0 & 1.3 & 39 & 20 & 325 & Abnormal genitalia & Yes, rec, symp & 6.0 \\
\hline 2 & M & 34 & 3 & 38 & 11.1 & 6.4 & 73 & 106 & 259 & Normal genitalia & Yes, rec, symp & 6.2 \\
\hline 3 & M & 37 & 22 & 65 & 13.2 & 3.1 & 47 & 31 & 248 & Abnormal genitalia & Yes, rec, symp & 2.0 \\
\hline 4 & M & 35 & 40 & 50 & 13.4 & 9.9 & 387 & 172 & 68 & Abnormal genitalia & Yes & 4.6 \\
\hline 5 & M & 40 & 7 & 23 & 12.4 & 4.4 & 154 & 93 & nd & Abnormal genitalia & Yes, rec, symp & 4.2 \\
\hline 6 & M & 40 & 2 & 72 & 12.6 & 3.4 & 45 & 8,5 & 82 & $\begin{array}{l}\text { Abnormal genitalia, } \\
\text { nistagmus, OPF }\end{array}$ & Yes & 4.6 \\
\hline 7 & M & 40 & & & 5.8 & 3.2 & 52 & 30 & nd & $\begin{array}{l}\text { Abnormal genitalia, } \\
\text { nistagmus, OSF }\end{array}$ & No & 2.8 \\
\hline 8 & $M$ & 33 & 42 & 5 & 6.1 & 5.3 & 518 & 169 & 61 & Abnormal genitalia & Yes & 3.2 \\
\hline 9 & $\mathrm{~F}$ & 34 & 8 & 8 & 2.5 & 0.6 & 43 & 26 & nd & $\begin{array}{c}\text { Midfacial } \\
\text { hypoplasia, OPF }\end{array}$ & Yes, rec & 7.8 \\
\hline 10 & $\mathrm{~F}$ & 37 & 30 & 23 & 4.0 & 2.5 & nd & nd & nd & OSF & Yes, rec, symp & 7.8 \\
\hline 11 & $\mathrm{~F}$ & 40 & 90 & 12 & 7.6 & 5.5 & 94 & 76 & nd & $\begin{array}{l}\text { Coanal atresia, } \\
\text { polydactyl }\end{array}$ & Yes, rec, symp & 2.2 \\
\hline $12^{\circledR}$ & M & 37 & 2 & 17 & 9.7 & 6.5 & 194 & 160 & 505 & $\begin{array}{c}\text { Normal genitalia, } \\
\text { OPF }\end{array}$ & No & 2.73 \\
\hline $13^{\circledast}$ & M & 26 & 120 & 60 & 28.1 & 20.7 & 384 & 279 & 179 & $\begin{array}{l}\text { Normal genitalia, } \\
\text { OPF }\end{array}$ & Yes, rec, symp & 2.32 \\
\hline $14^{\circledR}$ & $\mathrm{F}$ & 40 & 7 & 55 & 9.12 & 6.1 & 210 & 115 & 448 & & yes & 1.2 \\
\hline $15^{\circledast}$ & M & 40 & 5 & 45 & 6.7 & 2.5 & 185 & 34 & 380 & $\begin{array}{l}\text { Normal genitalia, } \\
\text { OPF }\end{array}$ & No & 1.6 \\
\hline $16^{\circledR}$ & M & 36 & 18 & 41 & 13.7 & 9.9 & 119 & 454 & 380 & $\begin{array}{l}\text { Normal genitalia, } \\
\text { hyperpigmentation }\end{array}$ & Yes, rec & 1.64 \\
\hline NR & & & & & $\begin{array}{l}0.1-12^{\circ} \\
0.1-1.1\end{array}$ & $0.0-0.6$ & $13-82$ & $6-59$ & $8-147$ & & $60-100$ & \\
\hline
\end{tabular}

Pt.: patient; M: male; F: female; OPF: open posterior fontanel; OSF: open sagital fontanel; rec: recurent; symp: symptomatic; nd: not done, ${ }^{\circ}<1$ month; ${ }^{\circledR}$ : patients with isolated hypocortisolism; NR: normal ranges. 
The characteristics of hormonal patterns are shown in table 2. In all the patients with CCPHD, MRI revealed abnormalities of the anterior pituitary such as hypoplasia or agenesia, and/or thickness or absence of the pituitary stalk. In addition, most of them showed ectopic or absence of the posterior pituitary bright signal.

Upon diagnosis, HRT consisted in hydrocortisone p.o. (17 mg $/ \mathrm{m}^{2} /$ day) in all the patients, and l-thyroxine $(8-12 \mu \mathrm{g} / \mathrm{kg} /$ day) in patients 1 to 11 . Remission of cholestasis occurred at a median age of 65 days (range, 24 to 167 days). Patients with isolated hypocortisolism recovered from cholestasis faster than those with CCPHD $(p=0.01)$. Normalization of liver enzymes occurred at a median age of 90 days (range, 24 to 287 days) (Figure 1). After a median follow-up of 3.9 years (range, 1.2 to 7.8 years), none of the patients showed any permanent liver dysfunction. Throughout follow-up, patients with isolated hypocortisolism were re-evaluated, and all of them showed normal pituitary adrenal function, confirming the presence of a transient disorder (pt. 12 to 16). Consequently, hydrocortisone replacement therapy was withdrawn at a median age of 7.5 months. When permanent CCPHD and isolated transient hypocortisolism were compared in relation to their clinical presentation, the only noteworthy sign was that abnormal external genitalia in boys with CCPHD was observed in most of the patients, supporting the potential diagnosis of hypogonadotropic hypogonadism as one of the affected pituitary axes. Nevertheless, normal genitalia did not exclude hypopituitarism. The evaluation of adrenal axis did not show any significant difference in ACTH levels of CCPHD patients, compared with those with isolated transient hypocortisolism. However among the latter patients, two of them had slightly elevated ACTH plasma levels (Table 2). Biochemical liver pattern seemed to show a tendency towards higher levels of ALT and $\gamma \mathrm{GT}$ in the group of patients with isolated hypocortisolism, although differences were not significantly different.

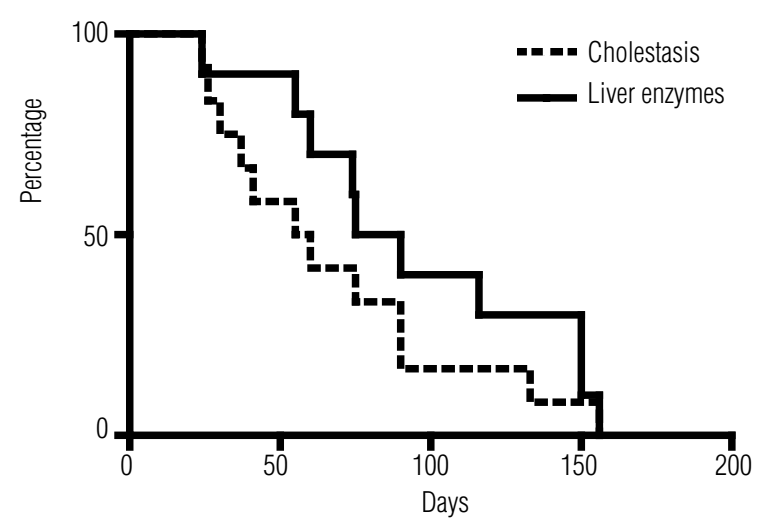

Figure 1. Remission time of cholestasis and elevated liver enzymes after hormone replacement treatment $(n=14)$ (Kaplan Meier curve).

Table 2. Hormonal assessment

\begin{tabular}{|c|c|c|c|c|c|c|c|c|c|c|c|}
\hline Pt & $\begin{array}{c}\text { Age } \\
\text { (days) }\end{array}$ & $\begin{array}{l}\text { Cortisol } \\
\text { (ug/dL) }\end{array}$ & $\underset{(\mathrm{pg} / \mathrm{mL})}{\text { ACTH }}$ & $\begin{array}{c}\text { FT4 } \\
\text { (ng/dL) }\end{array}$ & $\begin{array}{c}\text { TSH } \\
(\mathrm{mlU} / \mathrm{l})\end{array}$ & $\begin{array}{c}\text { PRL } \\
\text { (ng/mL) }\end{array}$ & $\underset{(n g / m L)}{G H}$ & $\begin{array}{c}\text { IGF-1 } \\
\text { (ng/mL) }\end{array}$ & $\begin{array}{l}\text { LH } \\
\text { (IU/I) }\end{array}$ & $\begin{array}{l}\text { FSH } \\
\text { (IU/I) }\end{array}$ & $\begin{array}{c}\text { To (ng/dL) } \\
\text { E2 } \\
\text { (pg/mL) }\end{array}$ \\
\hline 1 & 45 & $3.0^{*}$ & $<10^{*}$ & 0,6 & 10.6 & 9.0 & $5.4^{*}$ & UD & 0.06 & 0.1 & $<10$ \\
\hline 2 & 45 & $9.0^{*}$ & nd & 0.34 & 5.43 & 0.5 & $0.5^{\star}$ & UD & 9.5 & 7.9 & 440 \\
\hline 3 & 87 & 3.6 & nd & 0.72 & 8.01 & 22.1 & 0.54 & UD & 0.22 & 0.22 & $<10$ \\
\hline 4 & 90 & $<1.0$ & 12 & 0.72 & 5.16 & 41.0 & 3.1 & UD & $<0.1$ & $<0.1$ & $<10$ \\
\hline 5 & 48 & $<1.0^{*}$ & 19 & 0.62 & 9.86 & 13.0 & $4,6^{*}$ & 16 & 0.71 & 2.2 & $<10$ \\
\hline 6 & 15 & $<1.0$ & $<10$ & 0.72 & 5.92 & 144 & 1.9 & 22 & $<0.05$ & $<0.1$ & $<10$ \\
\hline 7 & 15 & $1.1^{\star}$ & nd & 0.62 & 5.00 & 144 & $1.5^{\star}$ & UD & 0.1 & 0.16 & $<10$ \\
\hline 8 & 102 & 0.6 & nd & 0.75 & 4.21 & 12.4 & nd & 9 & 0.77 & 1.77 & $<10$ \\
\hline 9 & 30 & $<1.0$ & $\mathrm{nr}$ & $<0.02$ & $<0.01$ & 0.5 & $<0.05$ & UD & $<0.1$ & $<0.1$ & nd \\
\hline 10 & 60 & $<1.0^{*}$ & $<10^{\star}$ & 0.5 & 6.86 & $<1.0$ & 0.15 & UD & $<0.1$ & 0.37 & 12 \\
\hline 11 & 53 & $1.1^{\star}$ & nd & 0.48 & 6.70 & 1.2 & $4.4^{*}$ & UD & nd & nd & nd \\
\hline $12^{\circledR}$ & 19 & 1.4 & $<10$ & 1.75 & 3.78 & 107.0 & 11.7 & 17 & 9.2 & 2.02 & 255 \\
\hline $13^{\circledR}$ & 43 & 1.7 & 27 & 1.28 & 4.60 & 95.3 & 18.6 & 38 & 4.05 & 1.96 & 190 \\
\hline $14^{\circledR}$ & 62 & 1.7 & 15 & 1.29 & 1.98 & 23.3 & $\mathrm{nd}$ & 29 & $<0.01$ & 1.35 & 15 \\
\hline $15^{\circledR}$ & 180 & 2.6 & 76 & 1.36 & 3.24 & 40.5 & nd & 20 & 4.32 & 2.17 & 111 \\
\hline $16^{\circledR}$ & 50 & $2.0^{*}$ & 79 & 1.52 & 5.81 & 34.4 & $12^{*}$ & 18 & 4.16 & 2.68 & 113 \\
\hline
\end{tabular}

Pt.: patients; M: male; F: female; ${ }^{*}$ performed under hypoglycaemia; nd: not done; UD: undetectable; na: not applicable; ${ }^{\circledR}$ : patients with isolated hypocortisolism, see text for normal references according to age and sex. 


\section{DISCUSSION}

When assessing infants with prolonged neonatal cholestasis, anamnesis and a careful physical examination provide additional tools to guide towards the underlying etiology of this disorder, due to the fact that most children are oligosymptomatic. Delayed diagnosis of an underlying endocrine disease predispose these patients to higher morbimortality risks due to the combination of recurrent hypoglycemia, acute adrenal insufficiency, and secondary hypothyroidism $(5,6)$. Since the initial report of CPHD in an infant with cholestasis and hypoglycemia by Blizzard and Alberts (7), several descriptions of case reports and few case series have been described.

Although it is not exactly known how hormone deficiencies cause cholestasis, the evidence of clinical and some experimental data supports the role of pituitary trophic hormones (cortisol, GH and thyroid hormones) in the pathogenesis of this disorder (8-13). Cortisol deficiency in adrenalectomized animals reduces biliary flow, which is reverted after treatment with hydrocortisone. $\mathrm{GH}$ also modulates the biosynthesis and secretion of biliary acids, and it has been shown that biliary flow recovers after hydrocortisone and GH treatment (1315). While there is not a pathognomonic biochemical pattern of liver dysfunction in relation to a particular hormone insufficiency, some reports have attempted to identify a pattern that leads towards this diagnosis. Some series have shown elevated transaminases in most of the patients. The proportion of our patients with abnormal elevated liver enzymes is similar to the observations of the other two large, previous series $(4,14)$.

On the other hand, serum levels of $\gamma \mathrm{GT}$, usually normal or slightly elevated in CPHD, have been proposed as useful tools to differentiate extra-hepatic disease from primary liver disorder (11). Moreover, Ellaway and cols. emphasized that the CPHD was a primary differential diagnosis in any child with cholestasis associated with normal or near normal $\gamma \mathrm{GT}$, and Wang and cols. concluded that normal $\gamma \mathrm{GT}$ levels could be predictors of severe but recoverable disease, such as hormonal insufficiencies $(6,16)$. Most of our patients with cholestasis had elevated $\gamma \mathrm{GT}$, highlighting that there is still no typical biochemical pattern of liver dysfunction associated to hormonal deficiencies. To our knowledge, and based on the series of cases already published, information is scare in relation to the liver dysfunction $(4,6,14,15,17-19)$.
Regarding other series, Binder and cols. reported that it took 88 days to normalize patient bilirubin when HRT was introduced, which is consistent with our series. Interestingly, they have shown that the earlier HRT is instituted, the faster the remission of cholestasis (14). In the series by Spray and cols., liver disease in 9 out of 12 infants resolved within 42 days following treatment with hydrocortisone, thyroxine, and/or recombinant human growth hormone (19).

It has been already described that cholestasis may be spontaneously resolved (before introducing HRT) in a minority of patients, as it happened with one of our patients $(4,18,19,20)$.

None of the previous reports have described the time to liver enzymes normalization after the start of HRT. We have shown that elevated liver enzymes take longer to normalize than cholestasis itself, although the time to normalization was quite variable. We believe this is valuable information for the pediatric hepathologist in relation to the follow-up of these patients.

Most of the patients from the first cases and series of cases reported underwent liver biopsy to rule out other causes of cholestatic jaundice. The usual pattern described in CPHD is "giant cell hepatitis" $(5,8,13,21)$. In our patients who showed physical findings consistent with hypopituitarism, liver biopsies were not carried out, assuming that the cholestasis was potentially a manifestation of hormone deficiencies $(4,14,19)$.

Hyperbilirubinemia began progressively to resolve a few days after HRT introduction in all our patients. Prompt improvement in bilirrubin levels reinforces the suspicion of an endocrine disease, preventing most of our patients from being submitted to additional invasive analyses, such as a liver biopsy.

The occurrence of transient hypocortisolism in infants has rarely been described. In five patients from our series, hypocortisolism resolved when adrenal axis was re-evaluated after 6 months of life. All of them showed isolated cortisol deficiencies, and in two of them, adrenal insufficiency was apparently primary, due to moderately elevated ACTH plasma levels at diagnosis. It is difficult to have a complete ascertainment if all these cases were really hypocortisolemia, since normal levels of serum cortisol in neonates can be quite low and overlap with abnormal values. However, in one of our patients, low cortisol levels were obtained under hypoglycemia. In addition, four of these patients also had recurrent hypoglycemia, and all biochemical parameters were similar to those patients with permanent hormone deficiencies. 
Interestingly, once HRT was introduced, remission of the cholestatic jaundice in patients with transient hypocortisolism occurred faster than those with permanent endocrine disease. A possible explanation for this finding could be that patients with multiple hormone deficiencies might have worse liver dysfunction than isolated hypocortisolism and, consequently, restoration to normal function takes longer. Recently, a few case reports have shown that transient hypocortisolism during infancy can be observed concomitantly to other diseases, such as a viral infection or hyperinsulinism $(22,23)$.

In summary, in our series, most of the cases of neonatal cholestasis and abnormal liver enzymes due to hormonal deficiencies in our patients resolved within 3 months after the introduction of HRT. None of the patients showed any permanent liver damage during follow-up; however, this can be the case if diagnosis is not suspected during infancy $(17,19)$.

We recommend that, in the presence of an infant with neonatal cholestasis, the occurrence of recurrent hypoglycemia and/or a specific phenotype consistent with hypopituitarism or hypocortisolism should orientate an endocrinological diagnosis and, consequently, shorten the referral to the pediatric endocrinologist.

Since cholestasis due to hormonal deficiencies completely resolves upon introduction of HRT, timely endocrinologic diagnosis as well as data on the course of neonatal cholestasis helps to optimize medical assistance of these infants, preventing unnecessary invasive studies.

Finally, once diagnosis of apparent isolated adrenal insufficiency is established, according to our series, this diagnosis might not be permanent. HRT should be offered and, once cholestasis is resolved, it is important to consider a re-evaluation of the pituitary adrenal axis since many of them might have transient hypocortisolism.

Disclosure: no potential conflict of interest relevant to this article was reported.

\section{REFERENCES}

1. Balistreri W. The liver and biliary system. In: Behrman R, Kliegman R, Jenson H, Nelson, editors. Textbook of Paediatrics, 16th ed. W.B. Saunders; 2000 p. 1194-207.

2. Suchy FJ, Balisteri WF, Heubi JE, Searcy JE, Levin RS. Physiologic cholestasis: elevation of the primary serum bile acid concentrations in normal infants. Gastroenterology. 1981;80:1037-41.
3. Suchy FJ. Neonatal cholestasis. Pediatr Rev. 2004;25:388-96.

4. Karnsakul W, Sawathiparnich P, Nimkarn S, Likitmaskul S, Santiprabhob J, Aanpreung P. Anterior pituitary hormone effects on hepatic functions in infants with congenital hypopituitarism. Annals of Hepathology. 2007;6(2):97-103.

5. Choo-Kang LR, Sun CJ, Counts DR. Clinical case seminar. Cholestasis and hypoglycemia: manifestations of congenital anterior hypopituitarism. J Clin Endocrinol Metab. 1996;81:2786-9.

6. Ellaway CJ, Silink M, Cowell CT, Gaskin KJ, Kamath KR, Donaghue, et al. Cholestatic jaundice and congenital hypopituitarism. J Paediatr Child Health. 1995;31:51-3.

7. Blizzard RM, Alberts M. Hypopituitarism, hypoadrenalism and hypogonadism in the newborn infant. J Pediatr. 1956;48:782-92.

8. Bauman JW, Chang BS, Hall FR. The effects of adrenalectomy and hypophysectomy on bile flow in the rats. Acta Endocrinol. 1966;52:404.

9. Macarol V, Morris TQ, Baker KJ, Bradley SE. Hydrocortisone choleresis in the dog. J Clin invest. 1970;49:1714.

10. Dumont M, Erlinger S. Influence of hydrocortisone on bile formation in the rat. Biol Gastroenterol. 1973;6:197.

11. Drop SL, Colle E, Guyda HJ. Hyperbilirubinemia and idiopathic hypopituitarism in the newborn period. Acta Paediatr Scand. 1979;68:277-80.

12. Giacoia GP, McGillvary MH. Neonatal hypothalamic hypopituitarism and liver dysfunction. NY State J Med. 1981;81:1652-55.

13. Poley JR, Smith JD, Thompson JB, Seely JR. Improved micellar dispersal of dietary lipid by bile acids during replacement therapy in growth hormone deficient children. Pediatr Res. 1977;12:1186-91.

14. Binder G, Martin DD, Kanther I, Schwarze CP, Ranke MB. The course of neonatal cholestasis in congenital combined pituitary hormone deficiency. J Pediatr Endocrinol Metab. 2007;20:695-701.

15. Sheehan AG, Martín SR, Stephure D, Scott RB. Neonatal cholestasis, hypoglycaemia and congenital hypopituitarism. J Pediatr Gastroenterol Nutr. 1992;14:426-30.

16. Wang J, Tan N, Dhawan A. Significance of low or normal serum gamma glutamyl transferase level in infants with idiopathic neonatal hepatitis. Eur J Pediatr. 2006;165:795-801.

17. Kaufman FR, Costin G, Thomas DW, Sinatra FR, Roe TF, Neustein HB. Neonatal cholestasis and hypopituitarism. Arch Dis Child. 1984;59(8):787-9.

18. Guideline for the evaluation of cholestasic jaundice in infants: recommendations of the North American society for pediatric gastroenterology, hepathology and nutrition. J Pediatr Gastroenterol Nutr. 2004;39:115-28.

19. Spray $\mathrm{CH}$, Mckiernan $\mathrm{P}$, Waldron KE, Shaw N, Kirk J, Kelly DA. Investigation and outcome of neonatal hepatitis in infants with hypopituitarism. Acta Paediatr. 2000;89(8):951-4.

20. Leblanc A, Odievre M, Hadchouel M, Gendrel D, Chaussain JL, Rappaport R. Neonatal cholestasis and hypoglycemia: possible role of cortisol deficiency. J Pediatr. 1981;99:577-80.

21. Herman S, Baggenstoss $A$, Cloutier M. Liver dysfunction and histologic abnormalities in neonatal hypopituitarism. J Pediatr. 1975;87:892-5.

22. Gupta V, Gupta VK. Apparent hypocortisolism in an infant with prolonged hyperinsulinism. Indian J Pediatr. 2010;77(3):321-2.

23. Akin L, Kurtoglu S, Kendirci M, Akin MA, Kardas F. Primary adrenal failure due to viral infection in an infant. Eur J Pediatr. 2010;169(7):887-9. 